\title{
EFFECTIVENESS OF HYBRID INTRAPERITONEAL MESH REPAIR FOR PARACOLOSTOMY HERNIA
}

Malgina $\mathrm{NV}^{1,2}$, Dolgina $T \mathrm{Yu}^{1,2} \otimes$, Epifanova $\mathrm{AD}^{3}$, Rodoman $\mathrm{GV}^{1,2}$

${ }^{1}$ City Clinical Hospital № 24, Moscow, Russia

${ }^{2}$ Pirogov Russian National Research Medical University, Moscow, Russia

${ }^{3}$ Sechenov First Moscow State Medical University, Moscow, Russia

\begin{abstract}
Due to advances in medical science, the frequency of surgical interventions that once ended in end-stoma formation has decreased significantly. An ostomy is a life-saving surgery performed when there are no other options. Unfortunately, the number of patients with life-threatening conditions requiring colostomy or ileostomy is growing. A stoma in itself is a cause of social alienation; stoma-associated complications reduce the quality of life and debilitate the patient. The aim of this study was to assess the effectiveness of hybrid intraperitoneal mesh repair of paracolostomy hernia using a modified EUROQOL 5D-5L questionnaire. Sixty patients with paracolostomy hernias included in the study were divided in 2 groups (30 persons per group). The experimental group (10 (33\%) men and 20 (67\%) women) and the control group (11 (37\%) men and 19 (63\%) women) were comparable in terms of sex $(p=0.787)$ and age (66.5 (62.2; 72.0$)$ years vs. 65.0 (61.25; 71.75$)$ years, respectively; $p=0.246$ ). Patients included in the control group underwent a classic Sugarbaker procedure; the experimental group underwent hybrid intraperitoneal mesh repair. The quality of life of the patients was evaluated before surgery and then 1 and 2 years after surgery using a modified EUROQOL 5D-5L questionnaire. Hybrid intraperitoneal mesh repair proved to be effective in the early and late postoperative periods. Based on the significant improvement of the patients' quality of life after hybrid intraperitoneal mesh repair, we conclude that this technique is an effective surgical treatment for paracolostomy hernias.
\end{abstract}

Keywords: paracolostomy hernia, quality of life, questionnaire, surgery

Author contribution: Rodoman GV — the final version of the manuscript; Malgina NV — study concept and design; Dolgina TYu — data acquisition, manuscript draft; Epifanova AD - statistical analysis.

Compliance with ethical standards: the study was approved by the Ethics Committee of Pirogov Russian National Research Medical University (Protocol № 160 dated December 19, 2016)

$\triangle$ Correspondence should be addressed: Tamara Yu. Dolgina Pistsovaya, 10, 127015, Moscow; dolgina-tamara@yandex.ru

Received: 10.07.2021 Accepted: 25.07.2021 Published online: 17.08.2021

DOI: 10.24075/brsmu.2021.037

\section{ОЦЕНКА ЭФФЕКТИВНОСТИ ПРИМЕНЕНИЯ ГИБРИДНОЙ ИНТРАПЕРИТОНЕАЛЬНОЙ АЛЛОПЛАСТИКИ ПРИ ПАРАКОЛОСТОМИЧЕСКИХ ГРЫЖАХ}

Н. В. Мальгина ${ }^{1,2}$, Т. Ю. Долгина ${ }^{1,2} 凶$, А. Д. Епифанова ${ }^{3}$, Г. В. Родоман ${ }^{1,2}$

${ }^{1}$ Городская клиническая больница № 24, Москва, Россия

2 Российский национальный исследовательский медицинский университет имени Н. И. Пирогова, Москва, Россия

${ }^{3}$ Первый Московский государственный медицинский университет имени И. М. Сеченова, Москва, Россия

Современный уровень развития медицины позволил значительно сократить частоту операций, сопровождающихся формированием концевых кишечных стом. Такие операции предпринимают для спасения жизни, когда невозможно поступить другим образом. К сожалению, из-за роста числа такого рода заболеваний число стомированных пациентов во всем мире увеличивается. Наличие стомы само по себе приводит человека к социальной дезадаптации, а осложненная стома стойко снижает качество жизни и трудоспособность. Целью исследования было оценить эффективность применения операции гибридной интраперитонеальной аллопластики параколостомических грыж при помощи оценки качества жизни пациентов на основании опросника EUROQOL 5D-5L. Включенные в исследование 60 пациентов с параколостомическими грыжами были разделены на две группы по 30 человек в каждой. Группа исследования (мужчины 10 (33\%), женщины 20 (67\%)) и группа сравнения (мужчины 11 (37\%), женщины 19 (63\%) были сопоставимы по полу $(p=0,787)$ и возрасту $(66,5(62,2 ; 72,0)$ лет и 65,0 $(61,25 ; 71,75)$, соответственно; $p=0,246)$. Пациентам первой группы была выполнена операция Sugarbaker, второй - гибридная интраперитонеальная аллопластика. Оценку качества жизни пациентов до операции, через год и через два года после нее осуществляли при помощи опросника EUROQOL 5D-5L. Показана эффективность гибридной интраперитонеальной аллопластики до операции и в раннем и позднем послеоперационных периодах. На основании значительного улучшения качества жизни пациентов после гибридной интраперитонеальной аллопластики можно сделать вывод о том, что эта операция является эффективным методом хирургического лечения пациентов с параколостомическими грыжами.

Ключевые слова: параколостомическая грыжа, качество жизни, опросник, хирургическое лечение

Вклад авторов: Г. В. Родоман - утверждение окончательного варианта статьи для публикации; Н. В. Мальгина - концепция и дизайн работы; Т. Ю. Долгина - сбор данных, написание текста статьи; А. Д. Епифанова - статистический анализ.

Соблюдение этических стандартов: исследование одобрено этическим комитетом РНИМУ им. Н. И. Пирогова (протокол заседания № 160 от 19 декабря 2016 г.)

$\bowtie$ Для корреспонденции: Тамара Юрьевна Долгина ул. Писцовая, д. 10, г. Москва, 127015; dolgina-tamara@yandex.ru

Статья получена: 10.07.2021 Статья принята к печати: 25.07.2021 Опубликована онлайн: 17.08.2021

DOI: $10.24075 /$ vrgmu.2021.037

Paracolostomy hernia is one of the late colostomy complications. According to different estimates, the rate of herniation after colostomy or ileostomy varies from 28 to $100 \%$ [1-6]. While a stoma in itself is a source of emotional distress for the patient, a parastomal hernia significantly reduces the patient's quality of life. Parastomal hernias can become painful, incarcerated or strangulated, lead to chronic evacuation difficulties, cause aesthetic discomfort and make it difficult to attach a colostomy bag [6-9].

To this day, paracolostomy hernias remain a surgical challenge [10]. Despite the diversity of surgical options for 
their repair, parastomal hernias recur in $14-50 \%$ of patients; reoperations increase the rate of recurrence up to 20-64\% [11-13]. Local tissue repair is characterized by a very high rate of parastomal hernia recurrence (46-100\%) [14]. Repair with synthetic mesh placed in a potentially contaminated wound (near the stoma site) is associated with a high risk of infection (27.6\%); therefore, a need may arise to remove hernia mesh in the early postoperative period, which may lead to hernia recurrence. Stoma relocation through open extraperitoneal ostomy is also associated with high hernia recurrence (75-100\%). Today, these methods have only historical value [10]. By contrast, the Sugarbaker technique and its modifications ensure the lowest rate of parastomal hernia recurrence $15 \%$ on average) [15; 16]. The high recurrence rate drives the search for new surgical techniques for parastomal hernia repair. One of such techniques, hybrid intraperitoneal mesh alloplasty, was proposed in our previous publication [17].

The aim of this study was to evaluate the effectiveness of hybrid intraperitoneal mesh alloplasty of paracolostomy hernia using a modified quality-of-life EUROQOL 5D-5L questionnaire.

\section{METHODS}

The study was conducted on 60 patients with paracolostomy hernias undergoing hernia repair between 2013 and 2019 at the City Clinical Hospital № 4, Moscow. Our study was a prospective single-center controlled continuous pilot trial of hybrid intraperitoneal mesh alloplasty effectiveness in patients with parastomal hernias. Sample size calculations were not performed. The study included patients with permanent stomas. The extent of surgical intervention which involved stoma formation was determined by the type of rectal disease: total abdominoperineal resection of the rectum for anal canal cancer; partial abdominoperineal resection for cancer of the rectal ampulla; colostomy for severe trauma of the anal sphincter [9].

The following inclusion criteria were applied: parastomal hernia confirmed by imaging tests which significantly compromised the patient's quality of life; clinical symptoms indicative of episodes of incarceration, documented bowel obstruction; informed consent to be treated, participate in the study and be followed-up for 2 years after surgery; willingness to follow medical advice. Exclusion criteria: allergies to iodinecontaining drugs; class IV-V of cardiac complications risk on the MNOAR (Moscow Scientific Society for Anesthesiology and Critical Care Resuscitation) scale [18]; Lee's class IV of cardiac complications risk (revised cardiac risk index) [19]; severe chronic obstructive pulmonary disease with FVC reduced to 70\%; mental disorders; impaired cognitive function; progressing or metastatic cancer; the possibility of stoma reversal surgery.

Patients included in the study were randomized into 2 groups. The control group comprised patients with paracolostomy hernia who were operated on using a classic Sugarbaker technique, i.e. tension-free intraperitoneal prosthetic mesh repair without defect closure [20]. The experimental group consisted of 30 patients who underwent hybrid intraperitoneal hernioplasty with composite mesh. This surgical intervention is a modification of the Sugarbaker technique. Briefly, the defect in the abdominal wall is closed with individual interrupted sutures so that it would match the diameter of the colon. Then the suture line and the anterior abdominal wall are reinforced with a composite mesh placed around the stoma to form an envelope for the colon. The mesh is secured with tacks to the parietal peritoneum and sutured to the serosa of the colon (Fig. 1-3). If properly performed, this technique prevents hernia recurrence during mesh integration with the native tissue. To sum up, the groups differed in terms of the applied surgical technique; the patients were randomly assigned to either group.

The groups were comparable in terms of parastomal hernia size: there were 20 (67\%) patients with type III hernia and 10 (33\%) patients with type IV hernia in the experimental group vs. 15 (50\%) and 15 (50\%) patients with type III and type IV hernia, respectively, in the control group $(p=0.191)$.

The overwhelming majority of our patients had a permanent stoma for anal canal cancer; of them $22(73 \%)$ were in the experimental group and 20 (67\%) were in the control group. The groups were comparable in terms of the underlying condition that necessitated a permanent colostomy $(p=0.763)$ The groups were also comparable in terms of initial surgical intervention $(p=0.394): 22(73 \%)$ patients in the experimental group and 17 $(57 \%)$ patients in the control group had total abdominoperineal resection of the rectum. Table shows the distribution of patients in the groups by their initial characteristics.

Early postoperative complications were evaluated using the Clavien-Dindo classification [21]. No deaths were registered in any of the groups. Most complications (surgical wound complications like seromas, postoperative hematomas, gastrointestinal paresis) were classified as grade I complications. Surgical site seromas were detected in $7 \%(2-21 \%)$ of patients from the experimental group and in 10\% (4-25\%) of patients from the control group (the difference was insignificant; $p>0.05$, Fisher's exact test). Surgical site hematomas were detected in $3 \%(1-17 \%)$ of control group patients vs. no hematomas in the experimental group. The proportion of patients with early postoperative gastrointestinal paresis was equal in both groups: $7 \%$ (2-21\%). Thus, the frequency of early postoperative complications did not differ significantly between the groups [17].

Late postoperative complications (parastomal hernia recurrence) were evaluated using follow-up contrast-enhanced CT scans of the abdomen performed 1 and 2 years after parastomal hernia repair. Two years after surgery, there were 3 parastomal hernia recurrences in the experimental group $(10 \%(3-26 \%))$ vs. 13 recurrences in the control group (43\% $(27-61 \%))$; the difference was statistically significant $(p=0.01$; Yates-corrected $\chi^{2}$ ). The most common late postoperative complications, besides parastomal hernia recurrence, are colostomy stricture and prolapse. In our study, there were no postoperative colostomy strictures in any of the groups. This may be explained by the use of composite mesh that does not erode into the bowel wall, cause deformation or stenosis of the

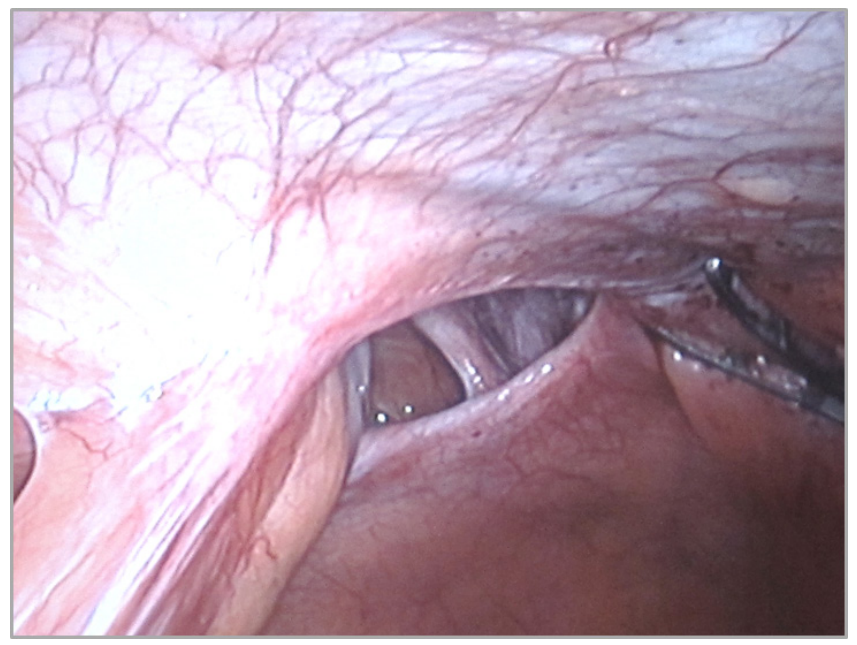

Fig. 1. An intraoperative image of the parastomal fascial defect 


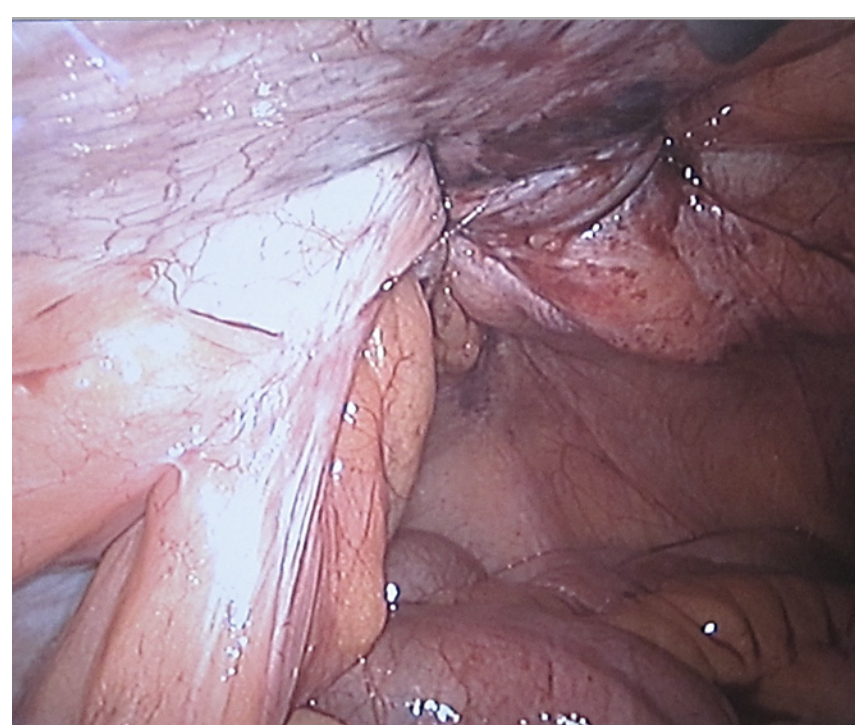

Fig. 2. An intraoperative image showing defect closure with sutures

bowel [22]. No cases of colostomy prolapse were observed in the experimental group. There were 3 cases of colostomy prolapse $(10 \%)$ in the control group. This complication was most likely due to the absence of fixation of the colon to the anterior abdominal wall at the ostomy site and higher colonic mobility. During hybrid intraperitoneal hernia mesh alloplasty, the colon is secured in place by adjusting the size of the defect to the colonic diameter so as not to leave any free space in this zone.

The quality of life of our patients was assessed using a European EUROQOL 5D-5L questionnaire. Our patients were mostly elderly people with chronic neurological comorbidities (cerebrovascular disease, chronic brain ischemia). It may be difficult for such patients to complete extensive questionnaires, and thus the results may be invalid and unreliable [9]. In our study, the quality of life was measured using a EUROQOL 5D-5L questionnaire before hernia repair and 1 and 2 years after hernia repair. These time points were chosen based on the international literature reports of paracolostomy hernia recurrences and our own data. Usually, paracolostomy hernias recur within one year after surgical repair $[15 ; 21]$.

The EUROQOL 5D-5L questionnaire consists of 2 sections. The first section focuses on 5 dimensions: mobility, self-care, usual activities, pain and discomfort, anxiety and depression. There are 5 levels of severity for each dimension: no problems, slight problems, moderate problems, severe problems, and extreme problems. In total, the questionnaire generates 3,125 different health states [23; 24].

We modified the questionnaire so that our respondents understood that they were evaluating the impact of paracolostomy hernia (but not other conditions) on their everyday activities and emotional state.

Below, we provide a modified version of the EUROQOL 5D-5L questionnaire [9].

1. Mobility:

a) My parastomal hernia does not cause any problems walking -1 point;

b) I have slight problems walking because of parastomal hernia -2 points;

c) I have moderate problems walking because of parastomal hernia -3 points;

d) I have severe problems walking because of parastomal hernia -4 points;

e) I am unable to walk because of parastomal hernia -5 points.

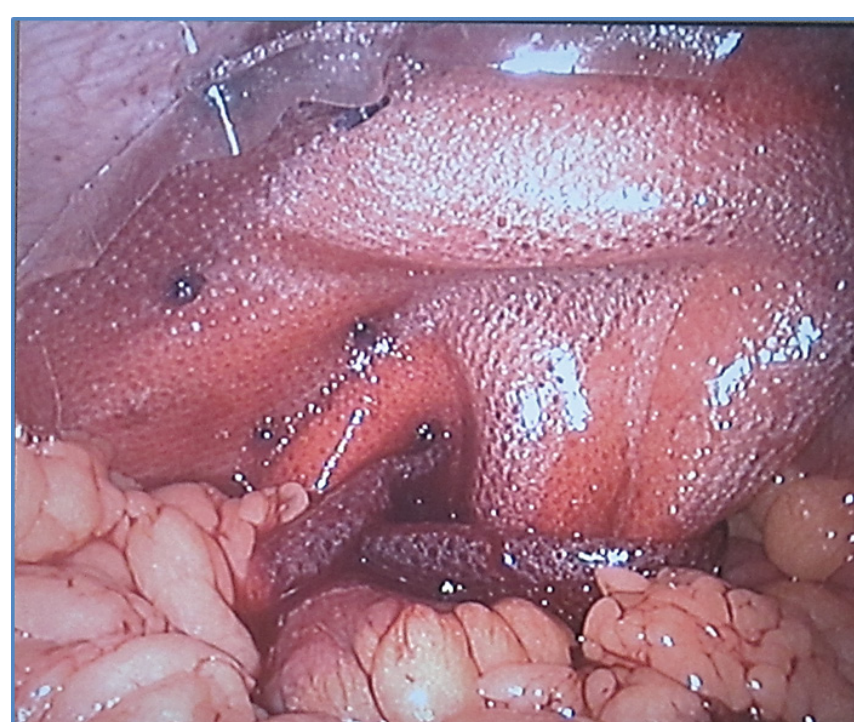

Fig. 3. An intraoperative image of the "envelope" for the colon

\section{Self-care:}

a) I have no problems dressing or washing myself - 1 point;

b) I have slight problems dressing or washing myself -2 points;

c) I have moderate problems dressing or washing myself - 3 points;

d) I have severe problems dressing or washing myself - 4 points;

e) I am unable to dress or wash myself because of parastomal hernia -5 points.

3. Usual activities (work, housework, family activities, leisure):

a) I have no problems doing my usual activities - 1 point;

b) I have slight problems doing my usual activities because of parastomal hernia -2 points;

c) I have moderate problems doing my usual activities because of parastomal hernia -3 points;

d) I have severe problems doing my usual activities because of parastomal hernia - 4 points;

e) I am unable to do my usual activities because of parastomal hernia -5 points.

4. Pain and discomfort:

a) I have no pain or discomfort - 1 point;

b) I sometimes have slight pain or discomfort that I link to parastomal hernia -2 points;

c) I sometimes have moderate pain or discomfort that I link to parastomal hernia -3 points;

d) I often have severe pain or discomfort that I link to parastomal hernia -4 points;

e) I almost always have extreme pain or discomfort that I link to parastomal hernia -5 points.

5. Anxiety and depression:

a) I am not anxious or depressed - 1 point;

b) I am slightly anxious or depressed -2 points;

c) I am moderately anxious or depressed - 3 points;

d) I am severely anxious or depressed -4 points;

e) I am extremely anxious or depressed -5 points.

The second section of the questionnaire is a visual analogue scale (VAS) that allows the patient to self-rate their general health from 0 to 100 (Fig. 4).

The respondent completes the questionnaire independently; it normally takes 2-3 min and does not pose any difficulty even for elderly patients with memory problems or cognitive impairment. The quality of life was evaluated by calculating a 
Table. Initial characteristics of patients included in the study

\begin{tabular}{|c|c|c|c|c|c|}
\hline Characteristic & $\begin{array}{l}\text { Total number of } \\
\text { patients }(n=60)\end{array}$ & $\begin{array}{l}\text { Experimental group } \\
\text { (hybrid intraperitoneal } \\
\text { mesh alloplasty) } \\
(n=30)\end{array}$ & $\begin{array}{l}\text { Control group (classic } \\
\text { Sugarbaker technique) } \\
\qquad(n=30)\end{array}$ & $p$ & Statistical test \\
\hline $\begin{array}{l}\text { Sex } \\
\text { Male } \\
\text { Female }\end{array}$ & $\begin{array}{l}21(35 \%) \\
39(65 \%)\end{array}$ & $\begin{array}{l}10(33 \%) \\
20(67 \%)\end{array}$ & $\begin{array}{l}11(37 \%) \\
19(63 \%)\end{array}$ & 0,787 & $\chi^{2}$ \\
\hline Median age, years & $65,5(61,75 ; 72.0)$ & $66,5(62,25 ; 72,0)$ & $65,0(61,25 ; 71,75)$ & 0,246 & Манна-Уитни \\
\hline $\begin{array}{l}\text { CParastomal hernia type } \\
\text { III } \\
\text { IV }\end{array}$ & $\begin{array}{l}35(58 \%) \\
25(42 \%)\end{array}$ & $\begin{array}{l}20(67 \%) \\
10(33 \%)\end{array}$ & $\begin{array}{l}15(50 \%) \\
15(50 \%)\end{array}$ & 0,191 & $\chi^{2}$ \\
\hline $\begin{array}{l}\text { Underlying condition } \\
\text { Cancer of rectal ampulla } \\
\text { Anal canal cancer } \\
\text { Diverticular disease complications } \\
\text { Rectal sphincter trauma }\end{array}$ & $\begin{array}{c}15(25 \%) \\
42(70 \%) \\
1(2 \%) \\
2(3 \%)\end{array}$ & $\begin{array}{c}7(23 \%) \\
22(73 \%) \\
0(0 \%) \\
1(3 \%)\end{array}$ & $\begin{array}{c}8(27 \%) \\
20(67 \%) \\
1(3 \%) \\
1(3 \%)\end{array}$ & 0,763 & $\chi^{2}$ \\
\hline $\begin{array}{l}\text { Initial surgery } \\
\text { Subtotal abdominoperineal resection of rectum } \\
\text { Colostomy } \\
\text { Total abdominoperineal resection of rectum }\end{array}$ & $\begin{array}{l}18(30 \%) \\
3(5 \%) \\
39(65 \%)\end{array}$ & $\begin{array}{c}7(23 \%) \\
1(3 \%) \\
22(73 \%)\end{array}$ & $\begin{array}{c}11(37 \%) \\
2(7 \%) \\
17(57 \%)\end{array}$ & 0,394 & $\chi^{2}$ \\
\hline
\end{tabular}

crosswalk index (weighted coefficient) using a EUROQOL 5D$5 \mathrm{~L}$ Crosswalk Index Value Calculator for Windows [24]. The difference between the crosswalk indices before and after treatment indicates the effectiveness of treatment. The following grading scale for treatment effectiveness was applied:
$\triangle E Q-5 D-5 L<0.10$ points - no effect
$0.10 \leq \triangle E Q-5 D-5 L \leq 0.24-$ minimal effect
$0.24 \leq \triangle E Q-5 D-5 L<0.31$ - satisfactory effect
$\triangle E Q-5 D-5 L \geq 0.31$ points - pronounced effect

The obtained data were processed in Python 3.8. (Guido van Rossum; Netherlands). Calculations were done using algorithms from the SciPy library. The Shapiro-Wilk test was applied to test the normality of distribution of quantitative variables. The test showed that the variables had non-normal distribution. Therefore, further analysis was performed using nonparametric statistics. Variables that had non-normal distribution are presented below as median values (Me), upper and lower quartiles $\left(Q_{1} ; Q_{3}\right)$. Independent samples were compared using the Mann-Whitney $U$ test; dependent samples were compared using the Wilcoxon test.
Possible correlations between quantitative variables were investigated using nonparametric statistics (Spearman's rank correlation coefficient, rs). Qualitative variables are presented below as absolute values, proportions (\%) and 95\%-Cl calculated by the Wilson method. Categorical variables were compared using Pearson's $\chi^{2}$. If the expected count in at least 1 cell was $<10$, Yates' correction for continuity was applied. If the expected count per cell was $<5$, Fisher's exact test was applied to measure the level of statistical significance. The significance threshold was set at $p \leq 0.05$.

\section{RESULTS}

Preoperative median values of the crosswalk index were comparable between the groups: $0.56(0.42 ; 0.69)$ in the experimental group and $0.46(0.29 ; 0 ; 68)$ in the control group ( $p=0.113$ ). Median VAS scores calculated before surgery were also comparable: $52.5(41.25 ; 67.5)$ in the experimental group and $47.5(40.0 ; 60.0)$ in the control group $(p=0.156)$.

Rate your health today on the scale from 0 to 100 ( 0 is the worst health you can imagine; 100 is the best health you can imagine)

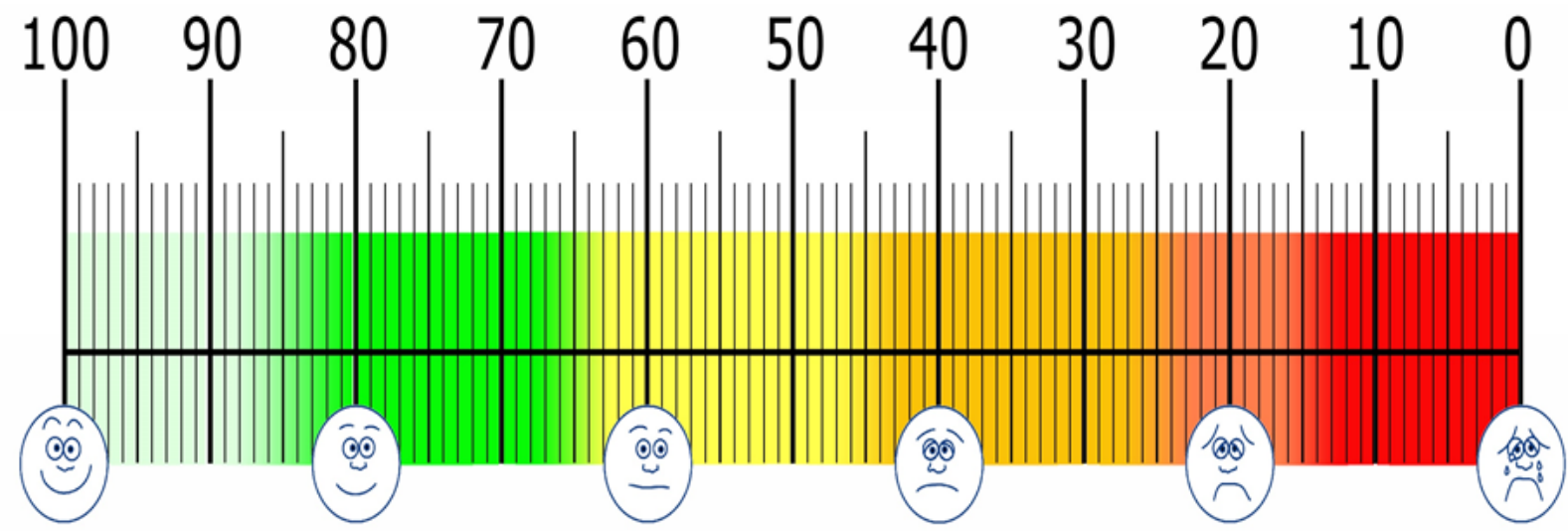

Fig. 4. The EUROQOL 5D-5L visual analogue scale 

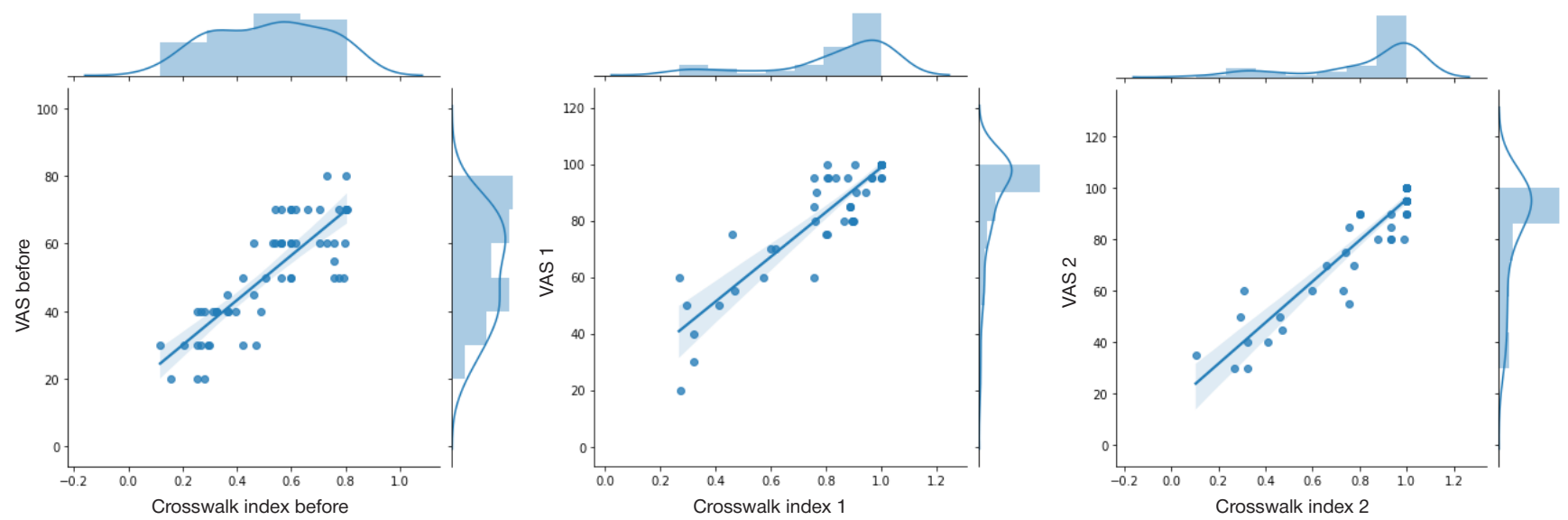

Fig. 5. Correlations between the crosswalk index and the VAS score

A year after surgery, the median crosswalk index and the median VAS score differed significantly between the groups $\left(p<0.001^{\star}\right.$ and $p<0.001^{*}$, respectively; ${ }^{*}$ designates statistically significant differences, i.e. $p<0.05)$. The median crosswalk index and the median VAS score were significantly higher in the experimental group than in the control group (crosswalk index: $0.92(0.81 ; 1.0)$ in the experimental group vs. $0.89(0.5 ; 1.0)$ in the control group, $p=0.046^{*}$; VAS score: 95.0 (86.25; 100.0) in the experimental group vs. $85.0(62.5 ; 100.0)$ in the control group, $p=0.021^{*}$ ).

Two years after surgery, the median crosswalk index was still significantly higher in the experimental group $(1.0(0.93 ; 1.0)$ than in the control group $\left(0.8(0.46 ; 1.0) ; p=0.048^{*}\right)$. Notably, the crosswalk index increased significantly in the experimental group in the second year after surgery from $0.92(0.81 ; 1.0)$ to $1.0(0.93 ; 1.0)\left(p=0.033^{\star}\right)$, whereas in the control group it fell from $0.89(0.5 ; 1.0)$ to $0.8(0.46 ; 1.0)\left(p=0.028^{\star}\right)$.

During the second year after surgery, the values of the crosswalk index in the experimental group were tight around $1((0.93,1.0))$, whereas in the control group they ranged from 0.46 to 1.0 , suggesting an unstable effect of surgery (measured by the crosswalk index) after 2 years. VAS scores were also higher in the experimental group than in the control group two years after surgery but the differences were insignificant: $95.0(85.0 ; 100.0)$ in the experimental group and 85.0 (50.0; 95.0) in the control group ( $p=0.054$ ). By year 2, the median VAS score in the experimental group stabilized at 95, without any significant dynamics. In the control group, the median VAS score remained at the same level (85) but the interquartile range expanded and shifted towards lower values, which was reflected in the statistically significant difference in VAS scores between years 1 and 2 after surgery: $85.0(62.5 ; 100.0)$ in year 1 vs. 85.0 (50.0; 95.0) in year $2\left(p=0.004^{\star}\right)$.

Importantly, the crosswalk index and the VAS score were well-correlated at all time points of measurement: before surgery $\left(r s=0.8246 ; p<0.001^{\star}\right), 1$ year after surgery $(r s=0.8909$; $\left.p<0.001^{\star}\right)$ and 2 years after surgery $\left(r s=0.9161 ; p<0.001^{\star}\right)$. In other words, the results generated by these two scales were in good agreement with each other (Fig. 5).

\section{DISCUSSION}

After hernia repair, median values of quality-of-life indicators improved significantly in both groups. However, the effectiveness of paracolostomy hernia repair is determined not only by an improvement in the quality of life but also by the proportion of patients without recurrent herniation [25].

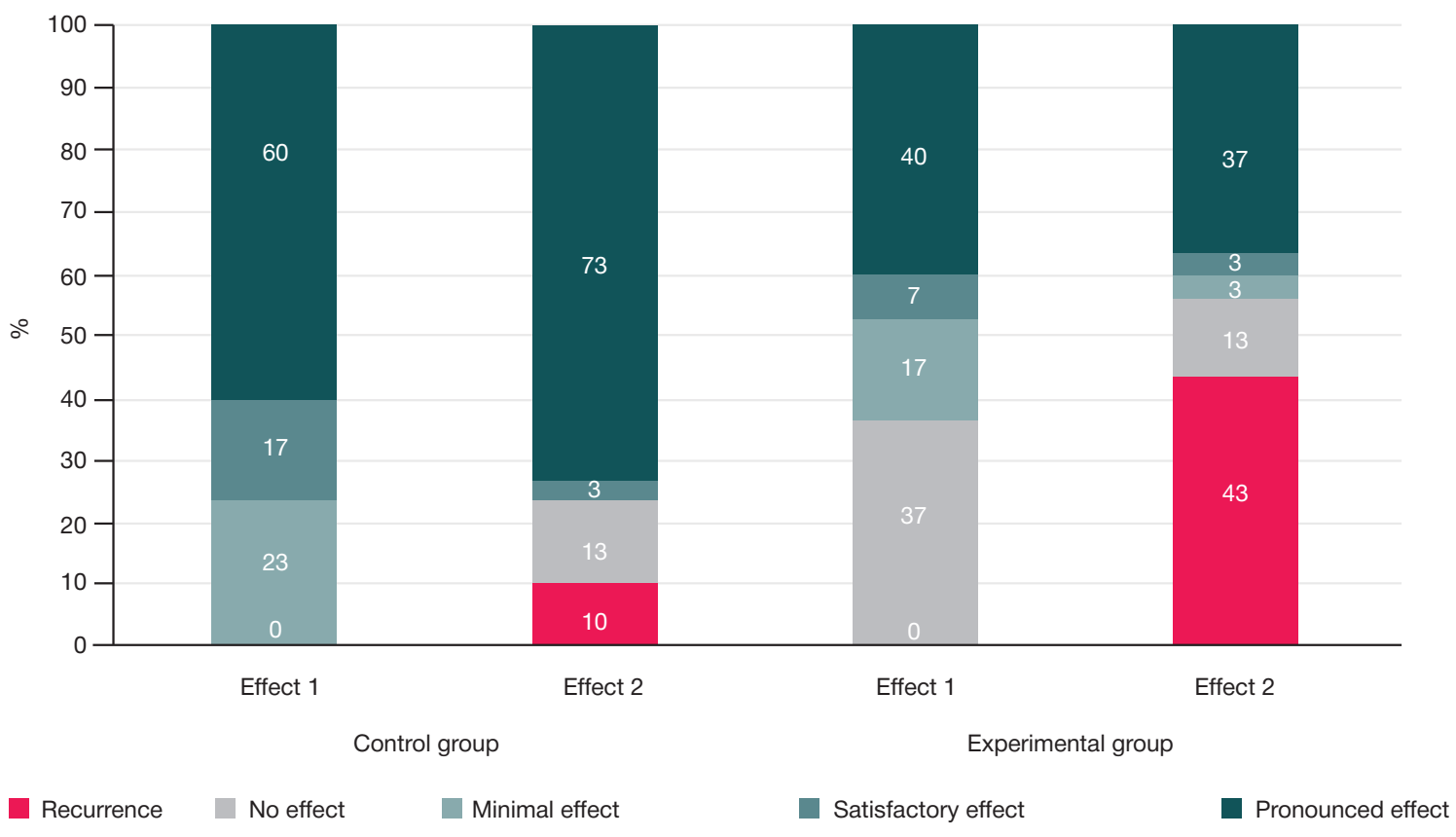

Fig. 6. Effectiveness of paracolostomy hernia repair 
The analysis of differences in the crosswalk index measured before surgery and 1 year after it (effect 1) and differences in this parameter measured 1 and 2 years after surgery (effect 2) showed that the effect of the delivered treatment was statistically significant (Fig. 6) in both groups 1 year after (effect $1 ; p=0.004^{*}$ ) and 2 years after surgery (effect $1 ; p=0.028^{*}$ ).

In terms of prevention of hernia recurrence, hybrid intraperitoneal hernia mesh repair in the experimental group had a significantly stronger effect $(90 \%(74 ; 97) \%)$ than the classic Sugarbaker technique in the control group (57\% (39; 73)\%); $\left(p=0.009^{*}\right.$; Yates-corrected $\left.\chi^{2}\right)$. The difference between the crosswalk indices before and after treatment allows assessing the effectiveness of the proposed surgical treatment based on the grading scale for effectiveness. Our findings may be useful for the planning of further studies and development of practical recommendations.

Our findings suggest that a follow-up abdominal CT scan might not be necessary in the late postoperative period after colostomy hernia repair. In a clinical setting, using the modified EUROQOL 5D-5L questionnaire may help to avoid a costly CT procedure. If the questionnaire shows that the patient's quality of life has not improved significantly after surgery and hernia recurrence is suspected, then a follow-up CT scan should be ordered.

In the late postoperative period, recurrent herniation was observed in 3 patients in the experimental group (10\%; 95\% Cl: $3-26 \%)$ and 13 patients in the control group (43\%; 95\% Cl: $27-61 \% ; p=0.01$; Yates-corrected $\left.\chi^{2}\right)$. The rate of recurrence in the experimental group was quite high. This raises the need for further refinement of the surgical technique and for new effective methods of parastomal hernia prevention [26-28].

The limitation of our study was a small sample size due to stringent inclusion criteria.

\section{CONCLUSIONS}

Parastomal hernia repair is a challenging surgical procedure without a clear standard of optimal surgical approach. Data collected by means of the modified EUROQOL 5D-5L questionnaire suggest that hybrid intraperitoneal hernia mesh alloplasty is an effective surgical treatment for patients with paracolostomy hernias that significantly improves the patient's quality of life. This technique can be recommended as a surgical treatment option for parastomal hernia.

\section{References}

1. Allen-Mersh TG, Thomson JP. Surgical treatment of colostomy complications. Br J Surg. 1988 May: 416-8.

2. Israelson LA. Preventing and treating Parastomal hernia. World Journal of Surgery. 2005; 1086-9.

3. Israelson LA. Parastomal hernias. Surgical Clinics of North America. 2008: 113-25.

4. Hiranyakas A, Ho YH. Laparoscopic parastomal hernia repair Diseases of the Colon \& Rectum. 2010; 53 (9): 1334-6.

5. Śmieta-ski M, Bury K, Matyja A, et al. Polish guidelines fo treatment of patients with parastomal hernia. Pol Przegl Chir 2013; 85: 152-80.

6. De Robles MS, Young CJ.BMC. Parastomal hernia repair with onlay mesh remains a safe and effective approach. 2020; 24; 20 (1): 296. DOI: 10.1186/s12893-020-00964-9.

7. Tivenius M, Näsvall $P$, Sandblom G. Int J. Parastomal hernias causing symptoms or requiring surgical repair after colorectal cancer surgery-a national population-based cohort study. Colorectal Dis. 2019; 34 (7): 1267-72. DOl: 10.1007/s00384019-03292-4.

8. Van Dijk SS, Timmermans L, Deerenberg EB, et al. Parastomal Hernia: Impact on Quolity of Life? World J Surg. 2015; 39: 2596601.

9. Rodoman GV, Malgina NV, Razbirin VN, Dolgina TYu. Ocenka individual'nogo kachestva zhizni pacienta s parakolostomichesko gryzhej. Hirurg. 2019; 3-4: 14-23. Russian.

10. Rodoman GV, Malgina NV, Razbirin VN, Dolgina TYu. Sostojanie problemy operativnogo lechenija parakolostomicheskih gryzh. Hirurg. 2016; 10 (144): 24-30. Russian.

11. Hansson BM, Slater NJ, Schouten van der Velden AP, et al Surgical techniques for parastomal hernia repair: a systematic review of the literature. Ann Surg. 2012; 255: 685-95.

12. Tadeo-Ruiz G, Picazo-Yeste JS, Moreno-Sanz C, HerreroBogajo ML. Parastomal hernias: background, current status and future prospects. Cirugía Española (English Edition). 2010; 87 (6): 339-49.

13. Antoniou SA, Agresta F, Garcia Alamino JM, et al. European Hernia Society guidelines on prevention and treatment of parastoma hernias. Hernia. 2018; 22: 183-98.

14. Gregg ZA, Dao HE, Schechter S, Shah N. Paracolostomal Hernia Repair: who and when? Journal of the American College of Surgeons. 2014: 1105-12.

15. Szczepkowski M, Gil G, Kobus A. Parastomal hernia repair:

Bielañski hospital experience. Acta chirurgica lugoslavica. 2006; 53 (2): 99-102.

16. Okorji LM, Kasten KR. Diagnosis and Management of Parastomal Hernias. Dis Colon Rectum. 2019 Feb; 62 (2): 158-62. DOI: 10.1097/DCR.0000000000001293.

17. Rodoman GV, Malgina NV, Razbirin VN, Epifanova SV, Dolgina TYu, Kuznecov Al. Primenenie mul'tispiral'noj komp'juternoj tomografi dlja ocenki jeffektivnosti hirurgicheskogo lechenija pacientov s parakolostomicheskoj gryzhej. Hirurgija. Zhurnal im. N. I. Pirogova. 2021; (3): 36-41. Russian.

18. Burov NE. Kratkij obzor istorii MNOAR. K 50-letiju MNOAR. Anesteziologija i reanimatologija. 2013; (4): 77-82. Russian.

19. Lee TH, Marcantonio ER, Mangione CM, et al. Derivation and prospective validation of a simple index for prediction of cardiac risk of major noncardiac surgery. Circulation. 1999; 100 (10): 1043-9.

20. Sugarbacker PH. Peritoneal approach to prosrhetic mesh repair of parastomy hernias. Ann Surg. 1985; 201: 344-6.

21. Dindo D, Demartines N, Clavien P. Classification of surgica complications: a new proposal with evaluation in a cohort of 6336 patients and results of a survey. Ann Surg. 2004; 240: 205-13.

22. Rodoman GV, Malgina NV, Razbirin VN, Dolgina TYu. Vybor sinteticheskogo allotransplantata dlja operacij po povodu parakolostomicheskih gryzh. Hirurg. 2018; 9-10: 3-12. Russian.

23. The EuroQol group. EuroQol - a new facility for the measurement of health related quality of life. Health Policy. December 1990; 16: 199-208. Available from: https://doi.org/10.1016/01688510(90)90421-9.

24. Notes on the use of EQ-5D developed by the EuroQol Group, 2003, EuroQol Business Management, PO Box 44453006 AK Rotterdam, the Netherlands, Available from: www.euroqol org

25. Blackwell S, Pinkney T. Quality of life and parastomal hernia repair: the PROPHER study. Hernia. 2020; 24: 429-30.

26. Gachabayov M, Orujova L, Latifi LA, Latifi R. Use of Biologic Mesh for the Treatment and Prevention of Parastomal Hernias. Surg Technol Int. 2020 Nov; 28; 37: 115-9.

27. Cross AJ, Buchwald PL, Frizelle FA, Eglinton TW. Meta-analysis of prophylactic mesh to prevent parastomal hernia. Br J Surg. 2017 Feb; 104 (3): 179-186. DOl: 10.1002/bjs.10402. Epub 2016 Dec 22.

28. Pich J. Prosthetic mesh for the prevention of parastomal hernias. Am J Nurs. 2019 Apr; 119 (4): 49. DOI: 10.1097/01. NAJ.0000554548.93403.64. 


\section{Литература}

1. Allen-Mersh TG, Thomson JP. Surgical treatment of colostomy complications. Br J Surg. 1988 May: 416-8.

2. Israelson LA. Preventing and treating Parastomal hernia. World Journal of Surgery. 2005; 1086-9.

3. Israelson LA. Parastomal hernias. Surgical Clinics of North America. 2008: 113-25.

4. Hiranyakas A, Ho YH. Laparoscopic parastomal hernia repair. Diseases of the Colon \& Rectum. 2010; 53 (9): 1334-6.

5. Śmieta-ski M, Bury K, Matyja A, et al. Polish guidelines for treatment of patients with parastomal hernia. Pol Przegl Chir. 2013; 85: 152-80.

6. De Robles MS, Young CJ.BMC. Parastomal hernia repair with onlay mesh remains a safe and effective approach. 2020; 24; 20 (1): 296. DOI: 10.1186/s12893-020-00964-9.

7. Tivenius M, Näsvall P, Sandblom G. Int J. Parastomal hernias causing symptoms or requiring surgical repair after colorectal cancer surgery-a national population-based cohort study. Colorectal Dis. 2019; 34 (7): 1267-72. DOI: 10.1007/s00384019-03292-4.

8. Van Dijk SS, Timmermans L, Deerenberg EB, et al. Parastomal Hernia: Impact on Quolity of Life? World J Surg. 2015; 39: 2596601.

9. Родоман Г. В., Мальгина Н. В, Разбирин В. Н, Долгина Т. Ю. Оценка индивидуального качества жизни пациента с параколостомической грыжей. Хирург. 2019; 3-4: 14-23.

10. Родоман Г. В., Мальгина Н. В, Разбирин В. Н, Долгина Т. Ю. Состояние проблемы оперативного лечения параколостомических грыж. Хирург. 2016; 10 (144): 24-30.

11. Hansson BM, Slater NJ, Schouten van der Velden AP, et al. Surgical techniques for parastomal hernia repair: a systematic review of the literature. Ann Surg. 2012; 255: 685-95.

12. Tadeo-Ruiz G, Picazo-Yeste JS, Moreno-Sanz C, HerreroBogajo ML. Parastomal hernias: background, current status and future prospects. Cirugía Española (English Edition). 2010; 87 (6): 339-49.

13. Antoniou SA, Agresta F, Garcia Alamino JM, et al. European Hernia Society guidelines on prevention and treatment of parastomal hernias. Hernia. 2018; 22: 183-98.

14. Gregg ZA, Dao HE, Schechter S, Shah N. Paracolostomal Hernia Repair: who and when? Journal of the American College of Surgeons. 2014: 1105-12.

15. Szczepkowski M, Gil G, Kobus A. Parastomal hernia repair:
Bielañski hospital experience. Acta chirurgica lugoslavica. 2006; 53 (2): 99-102.

16. Okorji LM, Kasten KR. Diagnosis and Management of Parastomal Hernias. Dis Colon Rectum. 2019 Feb; 62 (2): 158-62. DOl: 10.1097/DCR.0000000000001293.

17. РодоманГ.В., Мальгина Н. В., Разбирин В. Н., Епифанова С. В., Долгина Т. Ю., Кузнецов А. И. Применение мультиспиральной компьютерной томографии для оценки эффективности хирургического лечения пациентов с параколостомической грыжей. Хирургия. Журнал им. Н. И. Пирогова. 2021; (3): 36-41.

18. Буров Н. Е. Краткий обзор истории МНОАР. К 50-летию MHОАР. Анестезиология и реаниматология. 2013; (4): 77-82.

19. Lee TH, Marcantonio ER, Mangione CM, et al. Derivation and prospective validation of a simple index for prediction of cardiac risk of major noncardiac surgery. Circulation. 1999; 100 (10): 1043-9.

20. Sugarbacker PH. Peritoneal approach to prosrhetic mesh repair of parastomy hernias. Ann Surg. 1985; 201: 344-6.

21. Dindo D, Demartines N, Clavien P. Classification of surgical complications: a new proposal with evaluation in a cohort of 6336 patients and results of a survey. Ann Surg. 2004; 240: 205-13.

22. Родоман Г. В., Мальгина Н. В, Разбирин В. Н, Долгина Т. Ю. Выбор синтетического аллотрансплантата для операций по поводу параколостомических грыж. Хирург. 2018; 9-10: 3-12.

23. The EuroQol group. EuroQol — a new facility for the measurement of health related quality of life. Health Policy. December 1990; 16: 199-208. Available from: https://doi.org/10.1016/01688510(90)90421-9.

24. Notes on the use of EQ-5D developed by the EuroQol Group, 2003, EuroQol Business Management, PO Box 44453006 AK Rotterdam, the Netherlands, Available from: www.eurogol org.

25. Blackwell S, Pinkney T. Quality of life and parastomal hernia repair: the PROPHER study. Hernia. 2020; 24: 429-30.

26. Gachabayov M, Orujova L, Latifi LA, Latifi R. Use of Biologic Mesh for the Treatment and Prevention of Parastomal Hernias. Surg Technol Int. 2020 Nov; 28; 37: 115-9.

27. Cross AJ, Buchwald PL, Frizelle FA, Eglinton TW. Meta-analysis of prophylactic mesh to prevent parastomal hernia. Br J Surg. 2017 Feb; 104 (3): 179-186. DOI: 10.1002/bjs.10402. Epub 2016 Dec 22.

28. Pich J. Prosthetic mesh for the prevention of parastomal hernias. Am J Nurs. 2019 Apr; 119 (4): 49. DOI: 10.1097/01. NAJ.0000554548.93403.64. 